\title{
DENOSUMAB ASSOCIATED WITH BONE DENSITY INCREASE AND CLINICAL IMPROVEMENT IN A LONG-TERM HEMODIALYSIS PATIENT. CASE REPORT AND REVIEW OF THE LITERATURE
}

\author{
Sylvie Dusilová Sulkováa ${ }^{1,2}$, Jiř̌́ Horáček ${ }^{3}$, Roman Šafránek ${ }^{1,4}$, Petr Gorun ${ }^{5}$, Ondřej Viklický, Vladimír Palička ${ }^{7}$
}

Hemodialysis Centre, University Hospital Hradec Kralové, Czech Republic ${ }^{1}$, Department of Internal Medicine II, Charles University, Faculty of Medicine and University Hospital, Hradec Králové, Czech Republic², Department of Internal Medicine IV, Charles University, Faculty of Medicine and University Hospital, Hradec Králové, Czech Republic ${ }^{3}$, Department of Internal Medicine III, Charles University, Faculty of Medicine and University Hospital, Hradec Králové, Czech Republic ${ }^{4}$, Hemodialysis centre BBraun Avitum, Ustí nad Orlicí, Czech Republic ${ }^{5}$, Department of Nephrology, Institute for Clinical and Experimental Medicine, Prague, Czech Republic ${ }^{6}$, Department of Clinical Biochemistry, Charles University, Faculty of Medicine and University Hospital, Hradec Králové, Czech Republic ${ }^{7}$

Summary: Denosumab is a human monoclonal antibody representing a novel therapy of osteoporosis. Contrary to always other antiosteoporotic drugs, it is not contraindicated in advanced chronic kidney disease, as its pharmacokinetic does not differ from patients with normal kidney function. However, published case reports in chronic kidney disease (CKD) patients stopped the therapy after single dose because of hypocalcemia. We present a case of successful treatment of osteoporosis in a young hemodialysis patient with repeated denosumab doses.

Key words: Denosumab; Bone density; Hemodialysis; Hypocalcemia; Parathormone

\section{Introduction}

Denosumab is a full length human monoclonal antibody binding to the receptor activator of nuclear factor kappa-B ligand (RANKL), mimicking the action of osteoprotegerin (OPG, natural decoy receptor of RANKL) and representing a novel therapy of osteoporosis, approved by FDA in 2010 (1). By its action on RANKL, denosumab reduces the signal that is essential for osteoclasts formation, maturation, function and survival. RANKL inhibition has no effect on osteoblasts.

Denosumab is not cleared by the kidneys. In chronic kidney disease (CKD) dose adjustment of denosumab is not required but calcium and vitamin $\mathrm{D}$ supplementation is strongly recommended (2).

So far, only few case reports or very limited case series describing the experience with denosumab in CKD have been published. They all stopped the therapy after single dose because of hypocalcemia $(3,4,5,6,7,8)$ (Table 1$)$.

We present a case of successful treatment of osteoporosis in a young hemodialysis patient with repeated denosumab doses.

\section{Case report}

A 30-year-old woman with end-stage renal disease (ESRD) has been hemodialyzed since 2002. In 2004, she underwent unsuccessful kidney transplantation. Genetic form of atypical hemolytic-uremic syndrome (HUS) was confirmed in 2006 and she has been treated with low-dose methylprednisolone and fresh-frozen plasma replacement since.

She suffered from severe back pain. Her concomitant secondary hyperparathyroidism (SHPT) has been well controlled using calcitriol (2005-2008) or paricalcitol (5-15 ug per week starting in 2008) respectively. In 2008, her T-score was -3.9 (DXA, lumbar spine) and -3.6 (total hip). Off-label alendronate between 2008 and 2011 was without any clinical effect.

After careful examination, in-label denosunab $(60 \mathrm{mg}$ s.c.) was first given in August 2011. Oral calcium together with nutritional vitamin D was supplemented accordingly. At six-month intervals, four further doses of denosumab were administered.

The bone turnover markers decreased considerably (Table 2). The decrease was sharp shortly after the start of therapy, but in the later period, bone turnover markers normalized. Of interest is namely a profound decrease of serum osteocalcin from $154.1 \mu \mathrm{g} / \mathrm{l}$ to $1.9 \mu \mathrm{g} / \mathrm{l}$ within two months after the first dose, but with further slight increase (these serum samples for bone markers assessment were taken always before denosumab administration). Vitamin D status was well presented with vitamin D supplementation (300,000 IU in regular three months intervals). 
Tab. 1: Published case-reports with denosumab use in advanced CKD stages (only 1 dose in all cases).

\begin{tabular}{|c|c|c|c|c|c|c|c|c|c|}
\hline Author & $\begin{array}{c}\text { No of } \\
\text { patients }\end{array}$ & $\begin{array}{l}\text { CKD } \\
\text { stage; } \\
\text { RRT }\end{array}$ & $\begin{array}{c}\text { Age } \\
\text { (years) }\end{array}$ & $\begin{array}{c}\text { Lowest } \\
\text { serum Ca }\end{array}$ & Symptoms & $\begin{array}{l}\text { Time point } \\
\text { of low Ca } \\
\text { (post dose) }\end{array}$ & $\begin{array}{l}\text { Serum PTH be- } \\
\text { fore denosumab } \\
\text { administration }\end{array}$ & $\begin{array}{l}\text { Serum } \\
\text { PTH after } \\
\text { denosumab }\end{array}$ & Note \\
\hline $\begin{array}{l}\text { McCormick } \\
\text { (2012) }\end{array}$ & $1(3)$ & HD & 61 & $1.34 \mathrm{mmol} / 1$ & fatigue & 1 month & $186 \mathrm{pg} / \mathrm{ml}$ & $1044 \mathrm{pg} / \mathrm{ml}$ & \\
\hline $\begin{array}{l}\text { Torregrosa } \\
\text { (2013) }\end{array}$ & 1 & $\begin{array}{l}\text { CKD } \\
3-4 \mathrm{~T}\end{array}$ & 64 & $1.91 \mathrm{mmol} / \mathrm{l}$ & \begin{tabular}{|l|} 
not \\
reported
\end{tabular} & 6 months & $442 \mathrm{pg} / \mathrm{ml}$ & $1745 \mathrm{pg} / \mathrm{ml}$ & \\
\hline $\begin{array}{l}\text { Ivanov } \\
(2013)\end{array}$ & 2 & $\begin{array}{c}\text { CKD } \\
4-5 \mathrm{~T} ; \\
\mathrm{HD} \\
\end{array}$ & $\begin{array}{l}64 \\
64\end{array}$ & $\begin{array}{c}1.96 ; 1.97 \\
\mathrm{mmol} / 1\end{array}$ & $\begin{array}{l}\text { not } \\
\text { reported }\end{array}$ & & $\begin{array}{l}>190 \mathrm{pmol} / \mathrm{l} \\
54,8 \mathrm{pmol} / 1\end{array}$ & $\begin{array}{l}>100 \mathrm{pmol} / \mathrm{l} \\
108 \mathrm{pmol} / \mathrm{l}\end{array}$ & $\begin{array}{l}\text { cinacalcet } \\
\text { not discon- } \\
\text { tinued } \\
\end{array}$ \\
\hline $\begin{array}{l}\text { Ungprasert } \\
(2013)\end{array}$ & 1 & CKD3 & 61 & $\begin{array}{c}\text { ionized } \\
2.3 \mathrm{mg} / \mathrm{dl}\end{array}$ & $\begin{array}{l}\text { carpopedal } \\
\text { spasm; QTc } \\
520 \mathrm{~ms} \\
\end{array}$ & & $520 \mathrm{pg} / \mathrm{ml}$ & $778 \mathrm{pg} / \mathrm{ml}$ & $\begin{array}{l}\text { intravenous } \\
\mathrm{Ca}\end{array}$ \\
\hline $\begin{array}{l}\text { Talreja } \\
(2012)\end{array}$ & 1 & CKD & 68 & $6.7 \mathrm{mg} / \mathrm{dl}$ & $\begin{array}{l}\text { general- } \\
\text { ized pain, } \\
\text { tenderness } \\
\end{array}$ & 11 days & not done & $409 \mathrm{pg} / \mathrm{ml}$ & $\begin{array}{l}\text { intravenous } \\
\mathrm{Ca}\end{array}$ \\
\hline $\begin{array}{l}\text { Agarwal } \\
\text { (2013) }\end{array}$ & 1 & $\mathrm{PD}$ & 58 & $6.3 \mathrm{mg} / \mathrm{dl}$ & tetany & 7 weeks & $315 \mathrm{pg} / \mathrm{ml}$ & $647 \mathrm{pg} / \mathrm{ml}$ & $\begin{array}{l}\text { intravenous } \\
\mathrm{Ca}\end{array}$ \\
\hline
\end{tabular}

Abbreviatios: $\mathrm{CKD}=$ chronic kidney disease; $\mathrm{RRT}=$ renal replacement therapy; $\mathrm{HD}=$ maintenance hemodialysis, $\mathrm{PD}=$ peritoneal dialysis, $\mathrm{Ca}=$ calcium; $\mathrm{PTH}=$ parathyroid hormone. Units are presented in accordance with the relevant reference.

Tab. 2: Bone metabolism markers in the course of denosumab treatment.

\begin{tabular}{|l|c|c|c|c|c|}
\hline & $\mathrm{Ca}(\mathrm{mmol} / \mathrm{l})$ & $\mathrm{PTH}(\mathrm{pmol} / \mathrm{l})$ & $25(\mathrm{OH}) \mathrm{D}(\mathrm{nmol} / \mathrm{l})$ & Osteocalcin $(\mu \mathrm{g} / \mathrm{l})$ & $\mathrm{CTX}(\mu \mathrm{g} / \mathrm{l})$ \\
\hline Reference range & $2.15-2.51$ & $1.6-6.9$ & $>75(\mathrm{recommended})$ & $11-43$ & $0.162-0.436$ \\
\hline Before the 1st dose & 2.40 & 5.5 & 31.6 & 154.1 & 1.600 \\
\hline Two months after 1st dose & 2.26 & 30.5 & not available & 1.9 & 0.256 \\
\hline Before the 2nd dose & 2.45 & 13.6 & 30.7 & 10.5 & 0.179 \\
\hline Before the 3rd dose & 2.68 & 5.0 & 113.0 & 26.3 & 0.297 \\
\hline Before the 4th dose & 2.63 & 7.0 & 60.8 & 33.9 & 0.724 \\
\hline
\end{tabular}

Note: Serum samples taken in interdialysis period (during out-patient visit in tertiary centre).

Predialysis serum calcium, phosphate and PTH concentrations were monitored on at least monthly basis. Phosphate concentration did not exceed $1.8 \mathrm{mmol} / \mathrm{l}$. Several episodes of asymptomatic hypocalcemia with concomitant increase in PTH levels were observed (Figure 1). They always responded to the adjustment of calcium supplementation and/ or paricalcitol administration and nutritional vitamin D supplementation was not interrupted.

No soft tissue calcifications were detected either on hands or on lumbar and thoracic spine lateral x-rays. Very mild wedge-shaped deformity of 11 th thoracic vertebral body remained stable, with no change on x-ray in October 2013. In 2010, ultrasonography revealed a small mass $(0.07$ $\mathrm{ml}$ ) behind the left thyroid lobe. In 2013, the same observer (J.H.) described a smaller mass $(0.03 \mathrm{ml})$ in the same location. In 2013, her lumbar spine and total hip T-score improved to -2.8 and -2.9 , respectively. Importantly, her back pain disappeared shortly after the first denosumab dose and did not occur again, which resulted in marked improvement of subjective feeling and quality of life.

\section{Discussion}

In CKD, the DXA interpretation is not straightforward. However, low bone density in our patient indicated osteoporosis, with likely contribution of long-term methylprednisolone and secondary amenorrhea. Moreover, it was symptomatic, and neither next years on hemodialysis nor awaited future kidney transplantation (following eculizum$\mathrm{ab}$ administration in her case) would improve it. Previous treatment with bisphosphonate therapy did not improve her status. That is why we indicated denosumab shortly after its approval as novel antiosteoporotic drug.

What is our experience? The administration of the drug was clinically well tolerated. There was a permanent clinical improvement, an increase in bone density, a sustained decrease of bone resorption markers and, in accord with the published case reports, also episodes of hypocalcemia associated with PTH increase (Table 2, Figure 1).

However, these episodes were asymptomatic, and we were always able to return her calcium and PTH levels to 


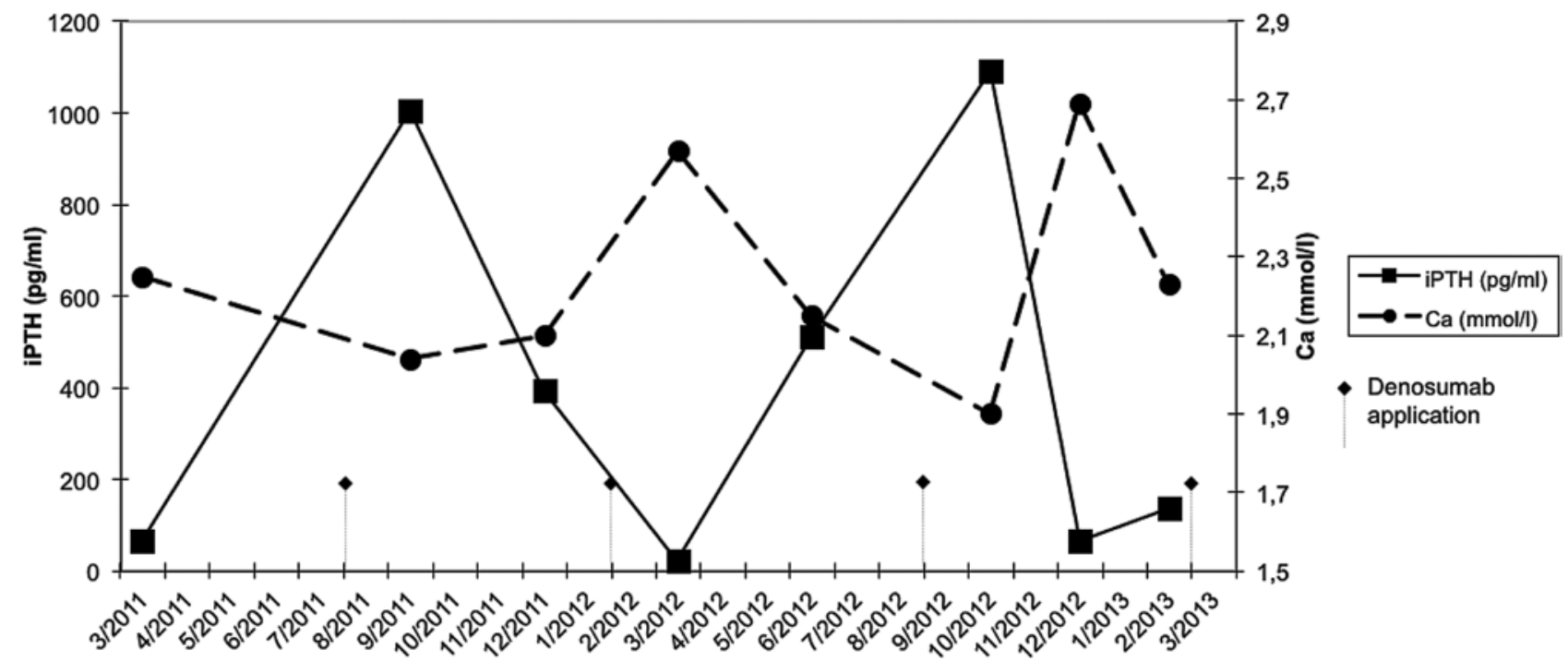

Fig. 1: Serum calcium a PTH (2011-2013)

normal within short time. Her secondary hyperparathyroidism remained responsive to conservative treatment with vitamin $\mathrm{D}$ receptor activators and her parathyroid glands did not enlarge.

Various explanations for denosumab-induced hypocalcemia in CKD patients have been presented. Westenfeld suggested hungry bone syndrome with prevailing activity of osteoblasts (9). In our case, however, the osteoblast activity actually decreased, as it is shown by decreasing osteocalcin concentrations (Table 2), which may be due to preserved association of osteoclasts and osteoblasts activity known in renal failure. Vitamin D deficiency would bring another explanation but in our case its levels were well controlled (Table 2). Cinacalcet, mentioned in another case report (4), was not used in our patient. Thus, the exact mechanism remains to be elucidated.

We consider the PTH increase to be a secondary response to hypocalcemia. We offer two parallel explanations why this response, i.e. PTH increase, is so sharp in endstage renal disease (ESRD): skeletal resistance to PTH (10) and the imbalance between RANKL and OPG. RANKL is eliminated during hemodialysis and its serum concentration in ESRD usually remains normal (11). Conversely, serum OPG concentration is increased $(12,13)$. The RANKL/OPG ratio thus becomes abnormally low in ESRD. This low ratio is actually further diminished by denosumab. This may lead to over-suppression of the osteoclasts activity and to very low bone resorption. Indeed, in our case there was an $85 \%$ decrease in CTX within two months. Due to skeletal resistance to PTH and low RANKL/OPG ratio associated with ESRD, mobility of calcium from bone is abnormally low. Much higher PTH-mediated stimulus for calcium release from bone is therefore needed.
The parallel decreases both in CTX as well as in osteocalcin level may tentatively be explained by a preserved coupling between osteoblasts and osteoclasts in ESRD.

The published case reports are summarized in Table 1. Nadir of serum calcium decrease was observed at variable time points (from 11 days to 6 months) $(3,4,5,6,7,8)$. This means that the risk for calcium decrease is continuous. Two authors did not report clinical significance, but remaining four authors observed clinical manifestation of hypocalcemia. In three of them, it was severe (tetany, generalized pain, carpopedal spasm, prolongation of QTc) (see Table 2). Concomitant administration of cinacalcet is definitely not recommended due to augmented risk of serum calcium decrease. Serum parathyroid hormone sharply increased in all but one patient. However, no further course of PTH is given in any of these reports, as all authors stopped denosumab administration after the first dose. McCormick concluded with the definite warning against denosumab administration in hemodialysis patients. Various aspects for the differences between our and published experience may be found, including unsupervised administration and insufficient laboratory and clinical monitoring.

Contrary to their opinion and warning, our experience with denosumab in CKD is positive. Though we also observed a fall in calcium associated with sharp rise in PTH levels, neither was critical, also because we anticipated them from the published reports, and adjusted the concomitant treatment accordingly. Especially, we fully normalized serum vitamin $\mathrm{D}$ concentration. We therefore strongly believe that the fear of hypocalcemia in hemodialyzed patients is not a contraindication of denosumab and the benefit of the drug is prevailing. 


\section{Acknowledgements}

Supported by Research Project NT/11355-4/2010 Ministry of Health of the Czech Republic.

\section{References}

1. Cummings SR, San Martin J, McClung MR, et al: Denosumab for prevention of fractures in postmenopausal women with osteoporosis. N Engl J Med 2009; 361: $33-41$.

2. Block GA, Bone HG, Fang L et al: A single-dose study of denosumab in patients with various degrees of renal impairment. J Bone Miner Res 2012; 27: 1471-1479.

3. McCormick BB, Davis J, Burns KD: Severe hypocalcemia following denosumab injection in a hemodialysis patient. Am J Kidney Dis 2012; 60: 626-628.

4. Torregrosa JV: Dramatic increase in parathyroid hormone and hypocalcemia after denosumab in a kidney transplanted patient. Clin Kidney J 2013; 6: 122; doi $10: 1093 / \mathrm{ckj} / \mathrm{sfs} 158$

5. Ivanov P, Khedr M: Prolonged hypocalcemia following a single dose of 60 ug denosumab in two patients with CKD4/5 on cinacalcet treatment for tertiary hyperparathyroidism. Clin Kidney J 2013; doi:10.1093/ckj/sft014
6. Ungprasert O, Cheungpasitporn W, Srivali N, et al: Life-threatening hypocalcemia associated with denosumab in a patient with moderate renal insufficiency. Am J Emergency Med 2013; 31: 756e1-756e2.

7. Talreja DB: Severe hypocalcemia following a single injection of denosumab in a patient with renal impairment. J Drug Assessment 2012; 1: 33-36.

8. Agarwal M, Csongradi E, Koch AC: Severe symptomatic hypocalcemia after denosumab administration in an end-stage renal disease patient on peritoneal dialysis with controlled secondary hyperparathyroidism. British J Med Medical Research 2013; 3: 1398-1406.

9. Westenfeld R, Ketteler M, Brandenburg VM: Anti-RANKL therapy - implication for the bone-vascular-axis in CKD? Denosumab in post-menopausal women with low bone mineral density Nephrol Dial Transplant 2006: 21: 2075-2077.

10. Fukagawa M, Kazama JJ, Shigematsu T et al: Skeletal resistance to PTH as a basic abnormality underlying uremic bone disease. Am J Kidney Dis 2001; 38: $152-155$.

11. Albalate M, la Piedra C, Fernandez C et al: Association between phosphate removal and markers of bone turnover in haemodialysis patients. Nephrol Dial Transplant 2006; $21: 1626-1632$

12. Gonnelli S, Montagnani A, Caffarelli C, et al. Osteoprotegerin (OPG) and receptor activator of NF-kB ligand (RANK-L) serum levels in patients on chronic hemodialysis. J Endocrinol Invest 2005; 28: 534-539.

13. Kazama JJ, Kato H, Sato T, et al: Circulating osteoprotegerin is not removed through haemodialysis membrane. Nephrol Dial Transplant 2002; 17: 1860-1861.

Received: $12 / 01 / 2014$

Accepted in revised form: 26/02/2014

\section{Corresponding author:}

Sylvie Dusilova Sulkova, M.D., Ph.D., prof., Hemodialysis centre; University Hospital Hradec Králové, Sokolská 581,50005 Hradec Králové, Czech Republic; e-mail: sylvie.dusilova@fnhk.cz 